\title{
Civil Society in the 2004 Romanian Elections: Watchdog, Involved Arbiter or Political Actor?
}

\author{
Aurelian Muntean ${ }^{1}$, Andrei Gheorghiță ${ }^{2}$ \\ ${ }^{1}$ National School of Political and Administrative Studies, Political Science Department, 6 Povernei, 71124 Bucharest, Romania \\ ${ }^{2}$ Lucian Blaga University of Sibiu, Department of Sociology and Social Work, 2-4 Lucian Blaga, 550169 Sibiu, Romania
}

KEYWORDS

Civil society

Elections

Trade unions

Election monitoring

Political parties

Romania

\section{A BSTRACT}

Civil society has proven outstanding capacities of involvement in the 2004 general elections in Romania and put a remarkable pressure on the political society. This paper aims to discuss the consequences of such involvement for both the political and civil society. We also investigate the conditions that have favoured a successful challenge of the main political actors by the most visible civic advocacy organizations. Further, we inquire how deep can an actor from the civil society go into the lands of the political society. In the end, we weight the achievements and the failures of civil society's active involvement in the game of elections.

\subsection{Civil society - general considerations}

Twenty five years ago civil society began to attract the spotlights of international and regional (from Eastern Europe) specialists and governments. It was more and more clear that civil society has the capacity to promote interests and ideas different from the official ones in totalitarian or autocratic regimes. Eastern Europe was about to experiment how movements generated and organized by civil society organizations (trade unions and churches) are dynamically generating the regime change (Elster, Offe and Preuss 1998; Howard 2003; Tilly 2004).

Civil society is a widely used concept not only in political science but also in politicians' discourses and media analyses. During the transition civil

\footnotetext{
${ }^{*}$ Contact addresses:

admuntean@gmail.com (A. Muntean), andrei.gheorghita@ulbsibiu.ro (A. Gheorghiță)
} 
society was considered almost a panacea for the consolidation of democracy. Although the concept of civil society is very used, its meanings are not always clearly underlined. In our paper we consider civil society as the realm of groups different from political parties, made of voluntary individuals having at a certain moment at least one common interest, aiming to influence politics, and obeying their actions to the legal framework. Thus, civil society embraces organizations like trade unions, religious organizations - including churches, political interest groups other than parties, civil rights NGOs. Often, in a very restrictive approach, usually endorsed by international assistance for the development of democracy, civil society is limited especially or even only to the civic advocacy NGOs (Carothers 1996: 65).

One of the features of civil society is constituted by the space where individuals and institutions representing their interests have the opportunity to develop the basis of different powers: power to influence the outcomes of policy-making process, power to legitimate collective actions in relations with the executive, power to demand a specific direction for the official decisions or the power to threat state's officials and to determine the adoption of certain measures (Dryzek 1996: 481-482). It is hard to believe that in a democratic regime the state (its official, empowered institutions) can be threatened so easily by civil society institutions. In fact a sounder explanation would be the capacity of bargaining that is shared by state institutions and civil society organizations. This partnership between state and civil society might be seen as a social "checks and balances" between the rulers and the ruled.

Which are the limits of civil society, concerning the component organizations? To answer to this question one must see what kinds of institutions are commonly considered as being part of the civil society. Diamond (1999) adopted an inclusive view. He argued that civil society comprises institutions from areas such as: economic, cultural, informational and educational, interest developmental, issue-oriented and civic. Civil society has specific features that particularize it from other arenas of society. It is different from the parochial society that Diamond sees as being concerned only with private aims, not public ones. It does not try to share the political power inside the state but to influence it. Further, civil society is 
seen as being based on plurality and diversity of actions inside the framework of social life. Moreover, it does not monopolize the representation of interests in favour of a single organization, but represents them through a multitude of associations, groups and organizations. At the same time, civil society's component institutions tend to be specialized in representation of certain groups and interests (Almond et al. 2003).

In this paper we will focus on two groups of civil society organizations: civic advocacy organizations and trade unions. They were the most active parts of civil society during elections. However, their activity had different aims and means to achieve them. Civic advocacy organizations joined a coalition and concentrated on 'cleaning' the party lists from 'Dalmatians' spotted candidates evaluated by civil society organizations to be unfit for being elected in the Parliament. Trade unions (part of them) aimed to pursue their interests directly in Parliament by promoting union leaders on party lists. In the next parts of the paper we will analyse both strategies in order to unveil the outcomes.

\subsection{Civil society in Romania: social relevance and future development}

Since 1989, the point of regime change and starting of redemocratization process, Romania organized five simultaneous general and presidential elections. Foreign and domestic civil society organizations were involved in monitoring elections since 1990 (see also Carothers 1996: 45). During every election process the opinions of election monitoring NGOs about the fairness of the process were highly debated in mass media.

Civil society continuously matured after 1989, although it is far from reaching the level of civic involvement, organization and activities that characterize the western civil societies (Howard 2003: ch. 4). The voice of NGOs began to be more powerful and the politicians started to take the NGOs more seriously (Carothers 1996: 68). There is no current evaluation on the total number of civil society organizations, how many of them are active, how many were registered during a specific period of time and the number of organizations that disappeared in the same period. At the time of 2004 general elections there were two partial evaluations of the overall number of civil society NGOs in databases of two resource NGOs: Civil Society 
Development Foundation (FDSC) and CENTRAS. FDSC collected information about organizations starting with the year 2000, using voluntary self filling questionnaires. According to CENTRAS database there in 2004 there were 1773 active NGOs. 118 were active within the primary or secondary field of advocacy while 194 were registered within the primary or secondary field of civil rights protection. About $12-14 \%$ of the total number of NGOs had as primary domain of activity the civil rights protection and advocacy. The FDSC database included a total number of 4190 active NGOs in 2004. Out of it, 483 NGOs were active in the field of civil rights and civic education, which represented $11.5 \%$ of the total.

The pool to offer civic advocacy organizations that might get involved in activities like election monitoring, public awareness or anti-corruption campaigns represents roughly $11-12 \%$ of the total number of civil society organizations. Of course, only a small part of this percent is active and finally gets involved in such activities, making it harder to develop powerful monitoring NGOs.

Civil society benefited from large financial, logistic, human and organizational assistance from international donors like USAID, IRI, NDI, NED, PHARE-EU, The German Marshall Fund, UNDP, Soros Foundation or IFES. Without their important assistance the activity of civic advocacy organizations might have been endangered or even inexistent. The effects of international assistance for civic advocacy NGOs were beneficial in terms of training and technical assistance for NGOs, but also in terms of development of new attitudes and opinions inside the society. Politicians and public authorities started "to give more consideration to certain basic rights such as free speech and due process, and to recognize publicly that oppositional politics and human rights advocacy are not the same" (Carothers 1996: 6869). Nonetheless, as Thomas Carothers underlines (1996: 69-70) the general impact of civic advocacy groups on public awareness and democratic civic consciousness is limited to the urban, educated, and political power-related groups.

The lack of alternative domestic financial assistance makes it very difficult for civic advocacy groups to develop organically and to secure a relative financial independence. Such time, human and financial consuming campaigns as the Coalition for a Clean Parliament in 2004 would have been 
impossible to exist in their full extension without the international assistance. Even though the partners of the Coalition have different fields of activity (civic awareness, think tank, media monitoring, human rights protection, student organization, journalism), thus increasing the expectation to be able to access different financial resources through grants, it is obvious that the limited number of donors for advocacy campaigns reduces very much the fund-raising field.

Civic advocacy groups are often based on voluntary activity of the mass of members. Instead, in Romania voluntary activity in this sort of organizations is very scarce. Recent analyses (Bădescu 2003; Voicu 2005) and opinion polls show that Romanians are not highly participative in voluntary associations. This is not the case that Romanians are an exception compared to other Eastern Europeans. Instead Romanians place above the average membership and active participation in civil society organizations (Howard 2003: 65-66).

Table 1. Membership and active participation in civil society organizations

\begin{tabular}{|lcccc|}
\hline \multicolumn{1}{|c|}{ Membership } & $\begin{array}{c}\text { Public Opinion } \\
\text { Barometer May } \\
\text { 2005 } \\
\text { (percentages) }\end{array}$ & $\begin{array}{c}\text { Active } \\
\text { participation } \\
\text { BOP May 2005 } \\
\text { (percentages) }\end{array}$ & $\begin{array}{c}\text { Panel survey* } \\
\text { November- } \\
\text { December 2004 } \\
\text { (percentages) }\end{array}$ & $\begin{array}{c}\text { Active } \\
\text { participation } \\
\text { Panel survey* } \\
\text { 2004 }\end{array}$ \\
(percentages)
\end{tabular}

* The panel survey was organized by Gabriel Bădescu, Grigore Pop-Elecheş, Marina Popescu, Paul E. Sum, Aurelian Muntean, and Andrei Gheorghiță through a joint-financing from University of Princeton, International Policy Fellowship Budapest, and Romanian National Council for Scientific Research in Higher Education (grant no. 382/2004 and doctoral scholarship 185/2003). 
Table 2. Trust in civil society organizations and in public institutions

\begin{tabular}{|c|c|c|}
\hline Trust very much and a lot in... & $\begin{array}{c}\text { Public Opinion Barometer } \\
\text { May } 2005 \text { (percentages) }\end{array}$ & $\begin{array}{c}\text { Panel survey* November- } \\
\text { December } 2004 \text { (percentages) }\end{array}$ \\
\hline Trade unions & $\mathrm{N} / \mathrm{A}$ & 20.8 \\
\hline NGOs & 28 & N/A \\
\hline Church & 83 & 83 \\
\hline Parliament & 21.7 & 20.1 \\
\hline President & 45.5 & 37.7 \\
\hline Government & 30.6 & N/A \\
\hline Army & 61.6 & N/A \\
\hline Juridical system & 24.9 & 28.2 \\
\hline Police & 36 & N/A \\
\hline Mass media & 61.3 & 53.9 \\
\hline Political parties & 12.4 & 16.1 \\
\hline $\begin{array}{l}\text { Mayor of the respondent's } \\
\text { residence place }\end{array}$ & 43 & N/A \\
\hline
\end{tabular}

* The panel survey was organized by Gabriel Bădescu, Grigore Pop-Elecheş, Marina Popescu, Paul E. Sum, Aurelian Muntean, and Andrei Gheorghiță through a joint-financing from University of Princeton, International Policy Fellowship Budapest, and Romanian National Council for Scientific Research in Higher Education (grant no. 382/2004 and doctoral scholarship 185/2003).

\subsection{Civil society and trade unions}

In order to influence state policies, citizens have to be members in "politically relevant groups" being able to influence politics in the direction of group's interests. (Lipset, Trow and Coleman 1956: 15). Trade unions, as well as other independent organizations in society increase the political socialization of their members. They serve as arenas in which new ideas are generated, networks through which citizens get acquainted with political attitudes, means for training future political leaders, means to get citizens to participate in political activities and bases of opposition to the central authority (Lipset, Trow and Coleman 1956: 80). Besides collective interests such as wages, working conditions and securing workplace, personal identification with a stance of a group, local tradition, membership in trade unions has other causes as well. Offe and Wiesenthal (1985: 184) argued that 
workers tend to organize themselves in trade unions because their potential for mobilizing sanctions (the principal tool to accomplish interests) is very weak as individuals by reason of their atomization of interests. Instead, the construction of this tool inside unions is more feasible and more effective, producing win-win situations in relation with the state institutions.

The post-communist changes influenced the positioning of trade unions in society. From a "transmission belt" role during communism, they switched to class interest organization and promotion. Trade unions moved from politically captured agents to opposition vis-à-vis the political and economic interests of parties and the state. Economic reforms impacted unions' basis - the membership - and determined trade unions to identify new means for influencing political agenda, as well as to change their interest set-up strategies in order to combine the interests of leaders and members. Trade unions are organized around collective and individual social and economic interests, sometimes opposed to the interests of political actors. Their most important resource is membership. This resource is transformed into power through the capacity of mobilization. During transition trade unions manifested as very active associative organizations: strikes, petitions and demonstrations are the principal high public impact actions; while personal contact with politicians and informal bargaining are highly used back-door methods but with less impact on public opinion.

However, trade unions' power decreased during transition (Perez Diaz 1993; Ost 1993; Iankova 2002). The increase of unemployment declined the membership of trade unions. The decline was influenced also by property change in the economy: in private companies the workers are not encouraged to join trade unions, although the legislative framework supports association in trade unions, while the employees do not put a strong pressure in this sense. In greenfield companies trade unions have fewer chances to organize collective action and the employees cannot joint such organizations, mainly because of the employers' reluctance towards unionisation, but also due to the increasing wages in a continuous development of Romania's economy after 1999. This reluctance is partly explained by the early equilibrium between trade unions and employers' associations: in the first ten years of transition trade unions were far better organized compared to employers' associations. 
The relations of civil society organizations with the state were dominated by trade unions. The pressure that unions have putted on government was higher than that used by other civil society organizations. Methods like strikes, demonstrations, picketing state institutions were of high impact in media and politicians took seriously the trade unions' pressures during bargaining. Some unions were used by various politicians as a pressure group to determine certain changes in the political status quo. The miners' marches towards Bucharest in the '90s (the first march took place in June 1990, the last march took place in February 1999) had a deep impact on public opinion attitudes towards trade unions. They were ever since 1990 considered less than a "civic" part of the civil society and more a "mass for political manoeuvres" in political competition. The decline of trade unions in terms of power, membership, capacity to mobilize people, is not as surprising as some authors argue (Ost 1993). In fact, there are several factors that could explain this decline:

(1) individuals had enough of false voluntary association in trade unions, since before 1989 unions were known as being an extension to the single party, and being a union member would increase the chances to receive a larger apartment, half-priced spa's tickets and even advances on professional hierarchy - all of these benefits vanished after 1989;

(2) the changes in the economy increased uncertainty - legal, institutional, social, welfare - thus, creating a "wild" incipient capitalism, in which trade unions barely tried to adapt themselves rather than focus on collective materialistic and post-materialistic issues; while individuals had to concentrate on personal welfare and securing their owns interests rather than pursuing collective ones, in an unpredictable environment;

(3) fragmentation of unionism, accompanied by chaotic union strategies as concerns political and economic issues, as well as internal democratization of unions and diversification of membership strategies;

(4) emergence of different possibilities to engage in collective associations different from trade unions, like religious associations and collective actions, sport association and neighbourhood or local community group initiatives; 
(5) structural incapacity of groups to identify collective common interests because of the reminiscent over-controlling and repressive/bureaucratic state as David Ost argues (1993: 456);

(6) trade unions are regarded as "relics of the past" (Ost and Crowley 2001: 219), and "Sleeping Beauties" that lost the contact with changes in society and cannot find their place in the current state of industrial relations (Kubicek 2004: 3);

(7) economic development decreased individual incentives for collective pursue of wealth and better jobs or employments conditions.

We can identify three trajectories that determine the perception of post-communist unions as being civil society organizations moreover closer to the political society than to the civil society: (1) violence as a result of social unrest and political influences determining the miners marches towards Bucharest; (2) trade unions struggle to promote their political interests either by forming their own parties - like in 1992 and 2004 elections, or by promoting union leaders on party lists (top concentration of union leaders MPs - 14 - was in 2000-2004 legislature); (3) union opposition towards economic reforms, associated with support for populist policies these strategies were seen by civil society organizations as an Achilles' heel in relation with the government, taking into account the fact that the majority of civil society organizations promoted straightforward liberal or at least centre-moderate attitudes, while the majority if not all the major trade unions support left or centre-left policies.

Other civil society organizations like civic advocacy ones were reluctant to cooperate with trade unions in civic actions (for example in the 2004 Coalition for a Clean Parliament). Trade unions were regarded with suspicion by civic advocacy organizations labelling unions as being "sold" to government, thus cannot be trusted in advocacy campaigns pursuing responsibility of MPs. It must be underlined that in spite of these attitudes trade unions managed to cooperate with other civil society organizations in actions like promotion of an Electoral Code (project of Pro Democracy Association) or the Constitutional Forum (civil society meetings with politicians in order to discuss the project to change the Constitution in 2003). The lack of trust might be explained by the fact that trade unions co-opted in civic actions did not manage to change the general impression about their 
capacity to take sides with civil society organizations. It is the case of Electoral Code Project that required two hundred fifty thousands signatures from citizens to be put on the Parliament's agenda - trade unions were informally accused by the civic advocacy partners in the project not to be active enough and to mobilize their members in order to collects their signatures. Collecting only 180,000 signatures while trade unions promote the idea that they have more than 3 millions members, helps understand the frustration of their civic partners that unions did not manage (or bother) to collect signatures and take a straightforward side.

However, unions are considered to have a significant blackmail potential, as a result of their actions' reflection in media. Since the government high ranking officials pay attention to what trade unions demand "on streets" sustained by thousands of workers and backed-up by the millions of members unions pretend to represent, attaching to unions a high pressure power seems rational. Unions are typical civil society organizations that interact very often with government, while pursuing collective (union) interests. Apart from the personal contacts union leaders have with governmental officials, trade unions have a privileged position being represented in the Social and Economic Council (the other members of the council represent employers' associations and the government). No other civil society organizations (apart from employers' associations) are represented in such consultative national councils. This position gives trade unions a specific power of bargaining with the government and influencing decision-making process.

\subsection{Civil society and elections}

Civil society organizations do not resume to merely influencing the decision-making process through specific methods like contacting officials, drafting and promoting laws, organizing strikes, demonstrations and boycotts or signing petitions. Their interaction with the political society is more complex and is based on historical legacies and precedents, international assistance and replication of more or less successful models of activities and strategies of behaviour. Thus, apart from general activities aimed to pursue interests, like the ones mentioned above, we identify three 
types of interaction between civil society and political society during elections.

The first type of interaction is represented by direct involvement in elections, support and promotion of "anti-political politics" - mass mobilization and political representation of interests through forums and organized movements that behave like large "umbrella organizations". Ever since the beginning of regime change in early 1989, civil society in Eastern Europe was very active in shaping the forthcoming founding elections. The interaction between civil society and political society at the electoral level impacted not only civil society's paths development during the transition, but also political parties' emergence. It is widely accepted that the civil society organizations opposing the communist regime in the ' $80 \mathrm{~s}$ determined the path of regime change, institutional arrangements and even political competition. The first post-communist large political organizations in Hungary, Poland, Czechoslovakia, Bulgaria, and Lithuania were acting in the first instance as civic organizations interested in politics, but keeping their organization away from party discipline, office seeking and bureaucracy (Tóka 2004: 124; Elster et al. 1998: 132-140). These civic-based political organizations dominated the first free elections. Two of the reasons for the initial success of these organizations were the managing of regime change process by round table negotiations, dominated by civic opposition; and the need to organize free elections in the shortest time, which impeded political organizations to develop genuine programs and ideologies (Elster et al. 1998: 134).

Involvement of civil society in election monitoring programs is the second type of interaction with the political society. Election monitoring can be defined as "purposeful gathering of information about an electoral process and public assessment of that process against universal standards for democratic elections by foreign or international organizations [and domestic civil society organizations] committed to neutrality and to democratic process for the purpose of building public and international confidence about the election's integrity or documenting and exposing the ways in which the process falls short [and intervening in the electoral process to correct imperfections caused by violation and ignoring of laws 
and standard procedures, while making recommendations for action]" (Bjornlund 2004: 40-41).

Dating from the 1980's monitoring elections is a fairly new form of civic activity during the elections. Its impact is in the same time hardly measurable but very important for different types of elections. We can identify several types of democratic elections assessed (1) in relation to the moment they are taking place vis-à-vis the point of regime change and (2) in relation to their importance and structural effects on democracy's development. The categories of elections are: regular, transitional, postconflict and consolidating (Bjornlund 2004: 35-36). Identifying the types of elections is very important in order to asses the importance of election monitoring organizations both from the monitored (authorities) and from the monitoring (domestic and foreign EMOs) point of view. The first election monitoring was organized in the mid '80s in Africa and South America. However, the boom in these activities took place in 1990 when the founding elections took place in Eastern Europe.

Romanian domestic civil society organizations, which are the focal point of our paper, got involved in election monitoring campaigns starting with the 1992 local and general elections. Their impact was often greater than that of international monitoring missions, due to the much higher number of observers mobilized by domestic EMOs (LADO and Pro Democracy Association) compared to the international EMOs (OSCE and US based organizations); a deeper observation of problems in polling stations; and "stirring up stronger feelings: positive and negative" about monitoring (Carothers 1996: 51).

Finally, the third type of interaction between civil society and political society is the straightforward supporting of certain political parties by civil society organizations, like trade unions, churches and NGOs. Trade unions develop ties with political parties because of the ideological approach and with the aim of better promoting union interests. Historically trade unions are closer to the left-wing parties, but after the Second World War some unions established close connections with centre-right parties, especially the Christian Democrats. The Catholic Church has an important ascendant upon the Christian Democratic parties. However, other denominations, especially the Orthodox Churches in Eastern European Orthodox majoritarian 
countries, tended to manifest as supporter of the governmental parties. This can be explained not as much as ideological and values similar orientations, but as a reminiscent strategy of supporting the state and its institutions through a "symphony" between the church and the state, dating from the communist period. There are cases when NGOs manifested as open supporters of specific candidates and political parties, as it was the case of the Coalition for Return, a Bosnian NGO that advised citizens to vote for certain candidates during the 1997 municipal elections (Chandler 2003: 232233).

\section{Civil society involvement in the 2004 elections}

\subsection{Data and methodology}

This article aims at discussing the consequences of civil society organizations' involvement in the 2004 electoral competition, both at the level of the political and civil society. Therefore, it tries to investigate the conditions that have favoured a successful challenge of the main political actors by the most visible civic advocacy organizations. Additional focus is given to the evaluation of achievements and failures associated to the civil society's active involvement in the game of elections. In order to cover these research goals, we made use of both qualitative and quantitative data. On the one side, we employed data collected through a series of extensive interviews with leaders of civil society organizations involved in the electoral competition: Ioana Avădani, executive director of the Center for Independent Journalism; Adrian Sorescu, executive director of the Pro Democracy Association; Cristian Pîrvulescu, president of the Pro Democracy Association; and Cristian Ghinea, journalist at Dilema weekly journal and former expert and program coordinator at the Romanian Academic Society. On the other side, we analysed quantitative data from the Public Opinion Barometer (POB) survey series of the Soros Foundation Romania and also from a panel survey organized in 2004 by Gabriel Bădescu, Grigore PopElecheş, Marina Popescu, Paul E. Sum, Aurelian Muntean, and Andrei Gheorghiță, through a joint-financing from Princeton University, 
International Policy Fellowship Budapest, and Romanian National Council for Scientific Research in Higher Education (CNCSIS) ${ }^{1}$.

\subsection{Civil society involvement in the 2004 elections. A general framework}

The 2004 general elections were dominated by the corruption issue. According to the Media Monitoring Agency, mass media generally focused on events, news, and political discourses that touched mainly the issue of political corruption. Other salient issues were the diplomatic successes like accession to the NATO and temporary closing of the negotiation chapters for the EU accession process and the reforms in major fields like public administration, justice and economics (free competition). The governing party - Social Democratic Party (PSD) - concentrated its campaign on the diplomatic and political successes, while the opposition - mainly the Truth and Justice Alliance (DA) - focused on the corruption of PSD and the lack of reforms in major fields. During elections, the major competitors accused each other of unfair competition and illegal actions with negative impact on the fairness of elections, still without being able to provide irrefutable evidences.

At the same time, the 2004 campaign came in a very tensed general political environment, after successive accusations of freedom of speech limitation and media control against the governing Social Democratic Party (PSD). Such accusations had been expressed not only by the opposition, but also by external actors and by the civil society. In this general framework, a vigorous implication of the civil society in the electoral competition came as a must, since the long-term political development and stability of the country were severely related to the results of the elections. It was not a matter of who wins or who loses, but of how to win. In the following sections, we shall focus on the mechanisms of electoral involvement chosen by the Romanian civil society. In each case, we shall discuss the consequences and implications of each program both for the political society and the civil society.

${ }_{1}^{1}$ CNCSIS research grant no. 382/2004 and doctoral scholarship 185/2003. 


\subsection{Civil society as involved arbiter}

The Coalition for a Clean Parliament (CCP) was probably the most complex politically-oriented initiative ever developed inside the Romanian civil society. It was designed as an anti-corruption awareness campaign, focused on the entire spectre of relevant political elites competing in parliamentary elections. On a first level, the complexity of such an initiative is easy to evaluate in numbers: ten of the most important civic $\mathrm{NGOs}^{2}$ have continuously worked together for over one year, assuming the role of arbitrating an electoral campaign foreseen as particularly dirty. On a second level, its complexity is given by the mix of actions involved: fund-raising, investigation, negotiation, public information campaign, all in an environment of sharp political pressures.

Briefly, the Coalition for a Clean Parliament aimed to promote the idea of integrity in politics, by the means of a broad public information campaign, "Vote with your eyes wide open!". Mainly, the campaign was a matter of highlighting the candidates considered unfit for public offices because of morality reasons. In such a démarche, civil society was intended to become a public arbiter that should make the rules of political integrity in the competition for the Romanian parliament and then point to those that do not fit such rules. However, this was not an easy job, since the general political context could be easily described in terms of predatory networked elites, generalized state capture, and media ownership control.

The CCP anti-corruption awareness campaign was designed as a sequence of six steps, conceived to offer the program legitimacy, visibility, and a remarkably high blackmail potential.

(1) The first step was to set the rules of the game. As a result of an open public debate inside the civil society, six individual criteria that would make a candidate unfit for "a clean Parliament" emerged: (a) having repeatedly shifted from one political party to another in search of personal profit; (b) having been accused of corruption on the basis of published and verifiable

\footnotetext{
2 The Romanian Academic Society (SAR), The Group for Social Dialogue (GDS), The Association of Political Science Students (APSS), Association for the Defence of Human Rights in Romania - Helsinki Committee (APADOR-CH), Pro Democracy Association (APD), Freedom House Romania, Center for Independent Journalism (CJI), Civic Alliance (AC), Media Monitoring Agency (MMA), and Open Society Foundation (OSF).
} 
evidence; (c) having been revealed as an agent of the Securitate; (d) being the owner of a private firm with important arrears to the state budget; (e) being unable to account for the discrepancy between one's officially stated assets and his/her income; and (f) turning a profit from conflicts of interest involving one's public position (Mungiu-Pippidi 2005: 7).

(2) Once the rules set, they needed a formal legitimacy from the main actors involved. Here came a series of discussions with the leadership of the parties represented in the parliament. The result has been the expected one, since the most important political parties publicly agreed with the criteria of the CCP and announced their support for the initiative - we should mention here the governing Social Democratic Party (PSD), the Humanist Party (PUR), electoral ally of PSD, the opposition National Liberal Party (PNL) and Democratic Party (PD), ${ }^{3}$ and finally the Democratic Union of Hungarians from Romania (UDMR). CCP's offer was rejected by the radical Greater Romania Party (PRM), the second important party in terms of parliamentary representation, but only a marginal competitor in the 2004 elections.

(3) The third step was to gather information about the candidates of the six main parties. The task of investigation at local level was assumed by one local journalist of investigation for each county, double-checked by a staff member of a local NGO branch and a senior journalist with responsibilities at regional level. The names of the investigators and reviewers remained anonymous, even for the organizations making part of the coalition. At this level, the result was a series of four 'black lists' with the names of the candidates considered unfit to hold a seat in the future parliament, because of meeting one or more criteria. The four lists corresponded to the two main electoral blocks - PSD+PUR National Union and PNL-PD Justice and Truth Alliance (DA) - and to the two remaining parties represented in parliament, Democratic Union of Hungarians from Romania (UDMR) and Greater Romania Party (PRM).

(4) The fourth step was to send the resulting 'black lists' to the corresponding political parties. It is the first point where the civil society makes use of its blackmail potential over the political society. Parties were

\footnotetext{
3 The National Liberal Party (PNL) and the Democratic Party (PD) were the constituents of the electoral alliance called Justice and Truth (DA).
} 
demanded to examine the case of each candidate and to decide whether to maintain or eliminate the candidates in question. The proposed exchange is clear: withdraw them or their 'sins' will go public once more. ${ }^{4}$ CPC clearly and publicly stated its availability for re-analysing any cases where individual candidates contested its findings (Mungiu-Pippidi 2005: 8).

(5) The next step was mainly a non-step for the CPC, since it assumed only a passive role. It was a period left for the political parties to re-analyse their initial candidates, having only three available options: withdraw, maintain or appeal to CPC. For a short period, the civil society dominated the pre-electoral scene, turning itself into some kind of a commission of discipline for the main political actors. Parties seemed unable or unwilling to react other way than conforming to the pressure from the civil society, and any form of appeal or contestation only came from individual candidates. PSD+PUR National Union withdrew about 30 candidates out of 143 from its electoral lists, some appeals from the candidates were accepted, so the final count of PSD+PUR Dalmatians ${ }^{5}$ was 95. DA Alliance withdrew 18 of 28 unfit candidates, and PRM and UDMR none (Mungiu-Pippidi 2005: 8) (Table 3).

Table 3. Initial black lists and final black lists of the CPC

$\begin{array}{lcc}\text { PSD+PUR National Union } & 143 & 95 \\ \text { PNL-PD Justice and Truth (DA) Alliance } & 28 & 10 \\ \text { Greater Romania Party (PRM) } & 46 & 46 \\ \text { Democratic Union of Hungarians (UDMR) } & 3 & 3\end{array}$

\footnotetext{
${ }^{4}$ The listed information brought nothing new, since CPC's accusations had been extracted from press materials published over the years or public sources of various state authorities. 5 The term 'Dalmatian' has been commonly used for the 'spotted' candidates, which did not pass the CPC's test of moral integrity.
} 
(6) The last step in the activity of CPC was to print and distribute the final black lists (containing exclusively the names of the remaining 'spotted' candidates) in the form of 1.6 million leaflets in most of the 41 counties of Romania. It's been an enormous information campaign that involved more than 2,000 volunteers. The real dimensions of this campaign are obvious if we think that daily print press readership in Romania was around $20 \%$ in the end of 2004, according to Soros Foundation's Public Opinion Barometer.

Table 4. Newspaper readership in Romania

\begin{tabular}{|l|c|c|c|c|c|}
\hline $\begin{array}{l}\text { On the average, how often do you } \\
\text { read newspapers? }\end{array}$ & Daily & $\begin{array}{c}\text { Several } \\
\text { times a } \\
\text { week }\end{array}$ & $\begin{array}{c}\text { Several } \\
\text { times a } \\
\text { month }\end{array}$ & $\begin{array}{c}\text { Monthly } \\
\text { or rarer }\end{array}$ & Never \\
\hline $\begin{array}{l}\text { October 2004 Public Opinion } \\
\text { Barometer }\end{array}$ & $20.8 \%$ & $20.9 \%$ & $14.5 \%$ & $12.8 \%$ & $31.1 \%$ \\
\hline $\begin{array}{l}\text { May 2005 Public Opinion } \\
\text { Barometer }\end{array}$ & $19.3 \%$ & $20.0 \%$ & $14.4 \%$ & $14.5 \%$ & $31.9 \%$ \\
\hline
\end{tabular}

Source: Soros Foundation Public Opinion Barometer, October 2004 and May 2005.

Table 4.1. Newspaper readership in Romania (top three national newspapers)

\begin{tabular}{|l|c|c|c|}
\hline $\begin{array}{l}\text { On the average, } \\
\text { how often do you } \\
\text { read political news } \\
\text { in ... }\end{array}$ & $\begin{array}{c}\text { At least once per } \\
\text { week }\end{array}$ & Rarely & Not at all \\
\hline Adevărul & $10.1 \%$ & $18.8 \%$ & $68.9 \%$ \\
\hline Evenimentul Zilei & $9.3 \%$ & $18.8 \%$ & $69.6 \%$ \\
\hline Libertatea & $20.1 \%$ & $11.3 \%$ & $62.5 \%$ \\
\hline
\end{tabular}

Source: November 2005 wave of the panel survey organized by Gabriel Bădescu, Grigore Pop-Elecheş, Marina Popescu, Paul E. Sum, Aurelian Muntean, and Andrei Gheorghiță through a joint-financing from University of Princeton, International Policy Fellowship Budapest, and Romanian National Council for Scientific Research in Higher Education (grant no. 382/2004 and doctoral scholarship 185/2003).

Briefly, this has been the schedule of actions put into practice by the Coalition for a Clean Parliament. Though up to this level the succession of activities has already shown a remarkable and rather unique strategic effort 
from the civil society, there is a strong need to perceive this effort in the complex system of interactions with the other actors involved in the electoral campaign, namely the political parties/candidates and the media.

\subsubsection{Relationship with political parties}

We have a self-nominated arbiter, namely a significant part of the civil society. But who are the players? We should distinguish between parties as strategic players and candidates as contextual players. A clear bi-directional relation between $\mathrm{CCP}$ and the main parties is easily identifiable in four moments of the "Vote with your eyes wide open!" campaign.

Firstly, there was a moment of quasi-general agreement, with the occasion of CCP's step two. Seeking for a formal legitimacy, the actors from the civil society asked for a feedback from the political actors on the list of criteria employed. Of course, such a broad legitimacy was easy to receive at that very moment, since it wouldn't have been a good signal for a party to reject the desirable goal of having a moral political elite. At the same time, at that moment, the capacity of the civil society to put into practice such an ambitious program was really questionable. The result was that most political parties transmitted public statements of support for the CPC initiative, with the notable exception of the Greater Romania Party (PRM). No clear reaction is identifiable from the part of individual candidates, no matter their political origins.

The second phase comes when main political parties were asked to withdraw from their lists the spotted candidates ( $\mathrm{CCP}^{\prime} \mathrm{s}$ step five). At this level, different patterns of reaction are distinguishable. The Truth and Justice (DA) Alliance had a particularly favourable behavior. It was a normal strategic option for two opposition parties, openly claiming not to be involved within the corrupt networks of power. Further, it was obvious for both party leaders that in any comparison the DA Alliance would score much better in terms of black-listed candidates than the government party. There was also a second reason for one of the parties (PD) to agree and support $\mathrm{CCP}^{\prime}$ s initiative - the cleaning campaign was a perfect opportunity to force several internal opponents to do 'the step back' and, hence, to refresh the party's top leadership. 
In this second phase, the National Union PSD+PUR reacted very incoherently. The first reaction was to announce the exclusion from the lists of a certain number of candidates and the self-withdrawal of others for 'personal reasons'. A few days later, a significant change in the Union's strategy occurred, exactly one month before the parliamentary elections. This change took the shape of an incredibly aggressive campaign against the $\mathrm{CCP}^{\prime} \mathrm{s}$ initiative in every form of media. CCP was accused of being part of a larger conspiracy of the opposition and also of intending to violate the fundamental political right of a citizen to be elected. The Union's candidates were publicly encouraged to sue the authors of the 'black lists' and to ask the courts to ban the distribution of the CCP's leaflets.

The Democratic Union of Hungarians from Romania (UDMR) invoked its particular status of ethnic political party in demanding to be excepted from the CCP's procedures, but with no result. No candidate was dropped out from the lists by UDMR. The Greater Romania Party (PRM) continued to ignore all the inputs from the CCP.

Reactions from individual candidates are a particularly interesting aspect that deserves to be emphasized in this second phase. Typical patterns of behaviour related to:

(a) appeals, contestations, justifications, having as a unique goal the drop out from the black lists;

(b) public appeal in justice for defamation or contestation of CPC's initiative legal character - there are famous cases, all coming from National Union PSD+PUR candidates: a former head of a secret service, a former minister of justice, a former minister of defence, the president of the Senate etc.;

(c) different pressures against the senior staff of the Coalition;

(d) frequent cases of intra-party denouncements in an attempt to eliminate candidates better placed on the party lists.

The third phase in the CCP-parties relationship is related to the national information campaign, by the means of voluntary leaflet distribution (step six). It is a period of intense anti-CCP campaign on behalf of the National Union PSD+PUR. Media turned into a battlefield between the government party and its allies and the representatives of CCP. The Coalition was constantly accused of 'conspiracy', 'ill intentions', 'pseudo- 
civic terrorism' and its members were called 'a bunch of criminals'. ${ }^{6}$ Government-controlled media developed formats very similar to Bolshevik tribunals, with the only reason to attack the CCP. Beyond the declarative level, the National Union PSD+PUR asked the Central Electoral Bureau and ordinary courts to ban the CCP leaflets, but all judicial decisions were taken in favour of the Coalition.

On a fourth level, unidentified forces launched a broad campaign of fake leaflets distribution. These 'poisoned' leaflets used the CCP format, the CCP members' signatures, but the names of the PSD candidates had been replaced with DA Alliance candidates.

This virulent anti-CCP campaign of the government party and its allies has mainly had a reverse effect, by offering more visibility to the Coalition and raising the stake for its pro-integrity in politics campaign. What in normal conditions would have been just a marginal initiative from the part of the civil society, turned to be an unexpected success in terms of visibility and public awareness. And mostly all because of the excessive (and unreasonable) reaction of the National Union PSD+PUR to the CCP initiative, correlated to a positive and rather mature behaviour of the opposition parties.

\subsubsection{Relationship with the media}

Two perspectives should be considered in the media-CCP relationship: the perspective of the involved media and that of the uninvolved media. By involved we refer to the presence of actions that are far beyond the limits of the mass communication function assumed by the media, such as implication in the activities of or against the CCP.

At the level of involved media, a striking dichotomy arose, individual journalists versus media groups. On one side there were individual journalists that took effective part in the actions of CCP as investigators or reviewers in the elaboration of the unfit candidate lists. Most of them worked for the coalition under the strict reserve of anonymity and have finally been paid for their investigations. At the same time, on the CCP side, we have two

\footnotetext{
6 "Open letter to the Coalition for a Clean Parliament", from Dan Voiculescu, president of the Humanist Party (PUR), November 9th 2004.
} 
media-oriented (and media-originated) $\mathrm{NGOs}^{7}$ that assumed the recruitment and networking function for the local investigators.

On the other side, there were media groups (especially the Intact Group, belonging to the family of Dan Voiculescu, head of the Humanist Party) that developed a coherent and aggressive campaign against the initiative of CCP, in virtue of media ownership interests. It is mainly about national or local media groups owned by members of the PSD+PUR National Union or by groups with related interests.

If we think of uninvolved media, comments and materials on the Coalition activities have been regarded rather favourable or neutral. As one of the interviewees remarked, uninvolved media reflected $\mathrm{CCP}^{\prime} \mathrm{s}$ actions more or less favourable according to previously generated trust or mistrust in the actions of the Coalition partners.

\subsubsection{The CCP experience. What to learn?}

The Coalition for a Clean Parliament has been an outstanding effort of the Romanian civil society, both in terms of complexity and logistics. It is not easy to assess its success with relation to its declared goals. However, 98 black-listed candidates holding eligible positions haven't been elected to the parliament, as a result of having been either withdrawn by their parties or 'defeated by the voters' (Mungiu-Pippidi 2005: 8). This means an aggregated success (direct and possibly indirect) of about $48.5 \%$. The real success should probably be described in terms of reassessing the role, strength and opportunities of civil society to control and challenge the political society.

There are a few conditions that have largely contributed to the visibility of the program (see also Mungiu-Pippidi 2005: 16-18). Some of them are related to the general socio-political environment - we should mention here $(a)$ a general feeling of frustration and dissatisfaction related to the 'political class' among the population; $(b)$ a continuous external (EU, US) pressure towards effective anti-corruption programs, that has continuously highlighted the issue of political corruption.

\footnotetext{
7 The Centre for Independent Journalism (CJI) and the Media Monitoring Agency (MMA), both partners in the Coalition for a Clean Parliament.
} 
The others are related to the specific campaign environment of 2004: (c) the visible contrast in the public reactions of the main political forces in front of a campaign pro-integrity in politics; $(d)$ the governing party's (and its allies) extremely aggressive reaction against the $\mathrm{CCP}$, leaving a general impression of 'guilt covering'. This overreaction did nothing else than highlighting the actions and issues of the CCP and raising the stake of the anti-corruption game (that wasn't favourable at all to a governing party); (e) the ability of the main opposition force (DA Alliance) to manipulate the game of withdrawals into its own favour.

But what are the drawbacks of the CCP campaign? First, it has feebly reached its target (the average citizen) in a direct manner. By the time the leaflets have reached the public, the general opinion had already been framed by the main actors (parties, mass media). Second, the reached target (political elite) was different from the target aimed or declared (average citizen). The CCP took the things into its own hands, and only secondarily left the final voting decision to the citizen. Its relation to the political parties along steps 4 and 5 can easily be characterized as a 'moral blackmail'. Third, the means employed cannot be easily accepted as specific to the civil society. In fact, the CCP largely performed as a political actor with extra-powers due to its civil society origins. Nevertheless, it added more weapons in the electoral battleground that have easily reached the hands of the opposition. Unintentionally, the CCP transformed itself into a strengthener of campaign issues. Fourth, the Coalition's démarche is not entirely moral with respect to its declared target, the public, since its leaflets presented only the pieces of information that had failed the test of political blackmail before. Though this has been a strategic effect-maximizer decision, its moral character is questionable. Fifth, the CCP did not always succeed in ensuring a perfectly objective and equidistant application of integrity criteria at local level.

\subsection{Civil society as a watchdog of fair elections}

Domestic election monitoring has a rather long-standing tradition in post-communist Romania. And this tradition is largely associated with the names of two non-governmental organizations, Pro Democracy Association (APD) and the League for the Defence of Human Rights (LADO) that 
emerged in the early 1990s. During their first years of existence, both organizations have had rather similar evolutions, but in the late 1990s the latter one's existence followed a rather descendent curve. Usually, this involution is explained in terms of organizational incapacity of attracting external funding. Such a situation has normally translated into an increasing share of governmental funding which set serious limitations in its activities. In reverse, Pro Democracy had a stronger capacity of implementing viable external-funded programs and successfully set an extensive network of local county-level 'clubs'.

The 2004 electoral year set a première in the field of domestic election monitoring, since the previous NGO bipolarity has been broken. LADO did not succeed in the effort of setting up a network of volunteer observers for the general elections and played only a marginal role in the pre-electoral legislative negotiations. Under these circumstances, Pro Democracy assumed the pole position in the list of election monitoring organizations (EMOs).

In the second half of 2004, the Romanian parliament has been the scene of a largely-supported attempt to modify the electoral legislation. This was not an unusual situation, since modifications of the electoral rules became a tradition of every pre-electoral period. The novelty was that APD, as a representative of the civil society with a respectable tradition in election monitoring, was invited to take part in the activity of the parliamentary commission designated to prepare the legislative modifications. As it is easy to anticipate, APD was not intended to play an effective role in the commission's activity, but mainly to fulfil a need of extra-legitimacy for the legislator's decisions.

However, Pro Democracy was actively involved in the work of the commission by reassessing the need for a new Electoral Code and introduced a rather coherent law project, still not very well received. In spite of APD's efforts (with the support of a few leaders of the main opposition force, the DA PNL-PD Alliance), in the end, all the provisions of the civil society-originated code had been rejected or ignored by the parliamentary commission. Thus, the commission preferred to work on the existing laws and introduced only conjuncture changes. 
Unsatisfied with the result of the commission vote, Pro Democracy adopted a different strategy in its effort of influencing the parliament's decision. The next step translated into an open letter addressed to every MP indicating seven broad categories of reasons that made the law project incapable to secure the fairness and the transparency of the elections for the Senate and the Chamber of Deputies. More, the letter's provisions have been publicly presented in front of the deputies by a representative of the DA Alliance, but without any success. The law has been adopted in the form proposed by the commission.

Once all possible paths of conventional influence exhausted, Pro Democracy decided to take advantage of its privileged position of unique generally accepted non-partisan EMO. Both APD and the Government were aware that the lack of internal observers would have had severe consequences upon the legitimacy of the election results. This is why Pro Democracy was in the position of having a significant blackmail potential upon the Government. About two month before the elections APD decided to make use of it.

Specifically, the General Assembly of the Association publicly announced its decision to observe the electoral process only if the Law no. $373 / 2004^{8}$ became subject to changes in order to correct or eliminate the aspects that might have lead to fraud. The only public institution able to initiate such changes was at that moment the Government. Pro Democracy sent an open letter to the Prime Minister Adrian Năstase in which it presented its point of view.

For the first time, APD's aggressive style of negotiation seemed to be a winning decision (at least partially), since the Năstase government took the Emergency Decision no. 80/2004 that modified the Law no. 373/2004. It was not a radical change (only two of the seven problems highlighted by the APD were solved), but it was a gain in the effort of setting up more fair and transparent rules for the elections. The most important change was the 'liberalization' of electoral observation. ${ }^{9}$ Under these circumstances, APD announced its decision to observe the elections.

\footnotetext{
8 Concerning the organization of elections for the Chamber of Deputies and the Senate.

9 Since 1996, the successive election laws provided that internal observers could be accredited only for a single polling station and that each polling station could have only one observer.
} 
The first round of elections took place on November $28^{\text {th }}$ and gave birth to an enormous scandal related to presumed frauds. Pro Democracy accredited 3,565 observers in Bucharest and 32 counties, ${ }^{10}$ mainly targeting polling stations placed in rural areas, usually more vulnerable to fraud attempts. ${ }^{11}$ Observers' reports have been extremely negative, suggesting that every weak point of the electoral legislation had been frequently speculated. Multiple voting, electoral tourism, ${ }^{12}$ threaten or aggressed observers were only the top of the iceberg. Under these circumstances, the APD report emphasized the large probability for the election results to be biased by the increased level of fraud, estimated at about 3 to $5 \%$.

Signals coming from the opposition (DA Alliance) confirmed the APD reports, and the public discourse of the main civil society or political opposition leaders violently accused the government of electoral fraud. This whole debate, correlated with repeated errors in the process of vote counting, generated a general state of nervousness in the population. And the top of the cake was the rather small difference in the electoral scores of the National Union PSD+PUR (first placed) and of the opposition DA Alliance (second placed), placed within the limits of the electoral fraud previously stated by the civil society and the opposition.

This proved to be the right moment for the Pro Democracy Association to put more pressure on the Government in the issue of electoral legislation. It was a moment when APD's blackmail potential was at the highest level. So, the organization publicly announced its decision not to observe the second round of the elections, since the legislative framework was unable to ensure a reasonable level of fairness for the elections. Under these circumstances, considered APD, "the monitoring process is not able to contribute to the fairness of the elections, but only to the legitimization of the winners" (APD Report 2005: 52). During the first two days after the APD announcement, the Government reaction has been extremely feeble. Vigorous demands for APD to change its decision came from external actors, as the Delegation of the European Commission in Bucharest or the Embassy

\footnotetext{
${ }^{10}$ From a total of 41 counties.

11 About 2,500 observers reached rural areas.

12 People transported with buses in order to vote in multiple polling stations.
} 
of the United States, which did nothing than to put more pressure on the Government.

All these developments forced the Government to do a step back and the Prime Minister Adrian Năstase to publicly ask APD to continue the monitoring process for the second round of presidential elections. Pro Democracy conditioned its acceptance on a change in the legislation that could limit the possibilities of electoral fraud, especially the case of multiple voting. Five days before the elections, at the end of a meeting of APD with the staff of the Central Electoral Bureau (BEC) ${ }^{13}$ and with the representatives of the PSD+PUR Union and of the DA Alliance, it was adopted the Decision no. 105. This BEC decision stated $(a)$ the possibility of transit voters to vote only in special polling stations and $(b)$ offered free access for the EMOs to the voters' lists, in order to investigate the cases of multiple voting. This was a real success (though partial) for the Pro Democracy and the following (natural) decision was its acceptance to monitor the second round of the general elections.

The second round of the presidential elections took place on December $12^{\text {th }}$. Though the stake of the game was extremely high, the frequency of illegal behaviours decreased compared to the first round. APD observers faced similar challenges, but less frequent, as the organization's report mentioned.

Pro Democracy continued its monitoring effort in the post-election period, with the clear intention to 'set an example' for the future electoral processes. It set up the basis for a systematic process of identification of multiple voters (people who fraudulently cast their votes more than once, in different locations). As part of the pilot program, APD introduced in a large database the names and personal information of 9,322 electors located in the Ilfov county. ${ }^{14}$ The results were astonishing, since 351 of them (about $3.76 \%$ ) cast their votes at least twice on the territory of the county. Pro Democracy started legal proceedings against all the 351 fraudulent voters in the late spring of 2005. Since APD's financial and human resources were limited, the

13 The leading electoral authority in Romania.

${ }^{14}$ The county where the biggest number of fraud attempts and observer aggressions had been reported. 
organization challenged the official institutions of the state to continue its démarche in order to identify and punish all the cases of multiple voting.

\subsubsection{Indirect relationship with political parties}

Pro Democracy was not alone in monitoring the 2004 elections. There were a few other NGOs able to send impressive numbers of observers. But APD was the only 'large-scale' EMO with a clear non-partisan status. Since 1996, the legislative limitations in the number of observers accredited for one polling station have stimulated the emergence of the so-called "ghost organizations", EMOs with "a questionable commitment to an impartial, democratic process" (Bjornlund 2004: 227). In fact, these organizations were initiated 'in the proximity' of the political parties (mainly of the Social Democratic Party), with a clear intention to disrupt the activities of legitimate organizations and to reduce their presence at polling stations (OSCE/ODIHR Report, apud Bjornlund 2004: 227).

Table 5. Internal observers accredited in the Romanian 2004 general elections

\begin{tabular}{lrr} 
EMO & $\begin{array}{l}\text { Number of } \\
\text { accredited } \\
\text { observers }\end{array}$ & $\begin{array}{l}\% \text { of total } \\
\text { observers }\end{array}$ \\
\hline Pro Democracy Association (APD) & 3,565 & $37.6 \%$ \\
Organisation for the Defence of Human Rights & 1,731 & $18.2 \%$ \\
(OADO) & 1,179 & $12.4 \%$ \\
"Mihai Viteazul” Foundation & 784 & $8.3 \%$ \\
"Millenium" Foundation for Human Rights & 766 & $8.1 \%$ \\
EuroDEMOS Society Club & 445 & $4.7 \%$ \\
Romanian Youth Association for the United Nations & 298 & $3.1 \%$ \\
Others (22 other organisations) & 722 & $7.6 \%$
\end{tabular}

Source: "Alegerile parlamentare şi prezidențiale 2004" (Institute for Public Policy Report), p. 121. 
This tradition of "ghost organizations" continued in the elections of 2004, in spite of the changes in the electoral legislation. ${ }^{15}$ It is rather unclear the continuity in such practices, except for a questionable intention to legitimate frauds in the electoral process. However, these organizations turned to a marginal role in the 2004 elections.

Another attempt from the political parties to influence (or control) the observation process was by the placement of partisan observers on the lists of non-partisan EMOs, the so-called 'poisoned observers'. Pro Democracy had faced this problem before and in time developed self-protection mechanisms. However, no matter how severely filtered the observers are, there is never a 100\% certainty about their independent status.

\subsubsection{The monitoring experience. What to learn?}

Pro Democracy Association invested a lot of effort in the electoral observation in 2004. APD's effort was a mature one and has largely crossed the borders of ordinary observation. The Association put into practice a complex program of electoral monitoring, with all the connected implications. It is remarkable that APD has successfully become a first rank legislative actor, in spite of the sharp resistance from the political society. However, if its means can hardly be considered moral, it is certain that they were appropriate and effective.

It is also clear that APD was significantly more successful in putting pressure on the Government than on the Legislative. There are a few possible explanations for this state of things.

First, the Government was more aware of the external consequences of an APD decision not to observe the elections, mainly in terms of the legitimacy of results. Elections followed an extensive period of critiques addressed to the party in government by the US Embassy, the British Embassy or the Delegation of the European Commission in Bucharest, related to issues like the freedom of expression, media control, etc.

${ }^{15}$ Government Emergency Decision No. 80/2004 had liberalized the observation of elections by eliminating the restrictions in the number of observers per polling station, previously limited to one. 
Second, APD's blackmail potential reached its highest quotas when it became the only experienced and legitimate non-partisan EMO. There was no alternative of negotiation from the real civil society for the Government, so all has become a win-lose game, where APD successfully played its cards.

Third, APD's pressure came in a particularly tensed electoral environment. In such an environment, a no-step-back position of the Government would have produced severe damages for the image of the party, with a high potential of being speculated by the opposition. At the level of Parliament, responsibilities are more diffuse and, in consequence, the image damages less significant.

\subsection{Alternative programs of continuous monitoring}

Our review of the strategies and practices employed by the civil society in relating to the political society in the particular electoral moment of 2004 would not be complete without a short look on two other monitoring programs, Media Monitoring Reports and "Money and Politics".

Media Monitoring Reports was a program developed by the Media Monitoring Agency (MMA) and financed by the National Endowment for Democracy and Reporters sans Frontières. The program monitored the way Romanian media reflected the presidential candidates in the pre-electoral period. MMA's analysis was structured along both quantitative and qualitative criteria. Briefly, the report emphasized the presence of clear partisan positions in the content of news reflecting the electoral campaign. The explanation of such deviations is usually related to the media ownership interests.

Money and Politics was a program developed by the Pro Democracy Association (APD) and funded by the Canadian International Development Agency. The program did an external monitoring of the expenses of the main electoral actors for political advertising in relation to the declared incomes and to the legal expense thresholds. APD's report emphasized the huge discrepancies between the official incomes and the advertising expenses for the PSD+PUR National Union, but also for the PNL-PD Alliance (DA) and the extra-parliamentary New Generation Party (PNG). The report also indicated a general trend of directing more than half of the 
advertising expenditures towards the presidential candidates, in an attempt to speculate a supposed leadership effect.

\subsection{Crossing the border: trade unions become political actors}

A part of the civil society, namely trade unions, did not join the above mentioned campaigns. Some of the trade unions (National Confederation of Trade Unions - Cartel-Alfa and the Confederation of Democratic Unions in Romania - CSDR) kept a distance from the electoral competition and the election monitoring, swinging between involvement and observation of these two processes. Other trade unions were already involved in electoral campaigns. National Confederation of Free Trade Unions in Romania CNSLR-Frăția, a long term collaborator of the left-wing governmental party PSD promoted union leaders on PSD's election lists as it did in 2000 in the previous elections.

BNS (the National Union Bloc of Trade Unions) was attracted by the political competition and decided to establish its own party. Capturing an older and unknown party (National Democratic Party) BNS transformed it into the National Democratic Bloc Party (PBND) and after several negotiations with various other political parties joined the national extremist Greater Romania Party (PRM) during the elections. BNS managed to negotiate with PRM a joint list to be promoted during the 2004 general elections. The coalition between PBND and PRM passed the 5\% threshold. Thus, a part of civil society and of trade unions became a political competitor, exiting the civil society area.

It was not a singular case during the post-communist electoral process. In the 1992 elections, trade unions organized a political party that unsuccessfully entered the competition by establishing the Party of the Social Solidarity. It was the first large failure of trade unions in the tentative promotion of their interest directly at the decision-making level. A second case of unsuccessful civil society involvement in political competition was the 1996 participation of the Civic Alliance Party (PAC). The party emerged as a political arm of the Civic Alliance, the most known and active civil society organization in the early transition years. In spite of promoting 
highly professional intellectuals PAC did not manage to pass the 3 percent threshold in order to send representatives in the Parliament.

The latest tentative political involvement of BNS raises the questions about the impact of trade unions involvement in the 2004 electoral competition and whether trade unions do have the capacity to help parties gaining more votes if electoral agreements are signed. During every postcommunist election, Romanian political parties looked for electoral support that could be received from different groups, trade unions included. Trade unions augment their presence in political-like issues and tend to extend to the maximum the benefits they could receive in electoral years as a result of their interaction with parties. During electoral years political parties tend to be more opened to issues defended by unions - governmental parties need social stability, while the opposition parties tend to use the unions in order to acquire larger electoral support. Still, the idea of bilateral benefits appears to be doubtful due to lack of empirical evidences of the electoral support that trade unions finally offer to political parties. There is no evidence of the electoral benefits for parties as a result of electoral protocols signed with trade unions.

Table 6. Trust in trade unions (percentage of respondents)

\begin{tabular}{|ccccccccccc|}
\hline Mar & Jun & Sep & Dec & Jun & Nov & May & Nov & May & Nov & \\
$\mathbf{9 7}$ & $\mathbf{9 7}$ & $\mathbf{9 7}$ & $\mathbf{9 7}$ & $\mathbf{9 8}$ & $\mathbf{9 8}$ & $\mathbf{9 9}$ & $\mathbf{9 9}$ & $\mathbf{0 0}$ & $\mathbf{0 0}$ & \\
28 & 21 & 24 & 26 & 23 & 29 & 30 & 15 & 14 & 19 & + \\
50 & 53 & 49 & 57 & 57 & 55 & 60 & 66 & 69 & 65 & - \\
& & & & & & & & & & \\
May & Nov & Jun & Oct & May & Oct & May & Oct & Oct & & \\
$\mathbf{0 1}$ & $\mathbf{0 1}$ & $\mathbf{0 2}$ & $\mathbf{0 2}$ & $\mathbf{0 3}$ & $\mathbf{0 3}$ & $\mathbf{0 4}$ & $\mathbf{0 4}$ & $\mathbf{0 5}$ & & \\
24 & 21 & 24 & 25 & 17 & 17 & 23 & 18 & 24 & & + \\
55 & 58 & 63 & 63 & 65 & 63 & 64 & 59 & 56 & & - \\
\hline
\end{tabular}

Source: Open Society Foundation Public Opinion Barometer.

Note: The numbers in each cell represent rounded percentages. "+" stands for "a lot" and "very much" trust in trade unions; "-" stands for "few", "very few" and "not at all" trust in trade unions.

Romanian trade union confederations often argue in their interaction with the political actors that they represent their members' interests. Even when union leaders call for negotiations with the government and employers, or call for protest movements they call these in the name of 
'members' interest' or of 'union's interest'. Still, as the public opinion polls revealed after 1989, people see themselves moreover distant from unions and capitalize very little trust in trade unions as organizations.

In spite of the collaborative patterns between parties and trade unions, it seems that political parties do not obtain the pursued aims: mass electoral support fails to be collected; the visibility at the level of voters/union members does not increase; the relation with electorate is not better because of the fact that none of the two partners - union or party - is perceived by the electorate as having close relations with it and being concerned with voters' issues; the institutional trust did not increase during the years of electoral cooperation, as percentages in Table 6 suggest. The only benefit seems to be the social stability, which might be sufficient enough for parties to pursue electoral protocols with unions. On the other hand, unions do not gain much more, but even less, with the exception of very few union leaders that receive offices or eligible positions on party lists. Signing electoral agreements between unions and parties does not influence the voting preference for that particular party. The electoral agreements would have a contrary effect - the voters might consider the union-party agreement a top level affair that does not pursue members' interests/problems, but only the leaders' ones. Such cooperation would produce either a lose-lose outcome, in which both the parties and the trade unions lose trust, or win-lose outcome, in which office-seeking trade union leaders win places in Parliament or in government, while the parties lose places on their lists. These places could otherwise be filled with parties' own candidates, thus losing places in Parliament in case that trade union representatives decide to deject the coalition they formed with the party. This was the case in January 2005, when the union representatives of PBND in parliament broke their coalition with Greater Romania Party and got out of its parliamentary group joining informally the governmental right-wing coalition.

The alternative would be promotion of neo-corporatist arrangements in the form of collective bargaining and social pacts between state, trade unions and employers' association, that could provide a social peace necessary for the cabinet to implement policies impacting employees and employers. 


\section{Conclusions}

Civil society has proven outstanding capacities of involvement in the 2004 general elections in Romania, that haven't been anticipated by any of the political actors. No matter the success or the morality of its actions, this experience emphasized the need to reassess civil society's role, strength and opportunities to control and challenge the political society in an electoral environment. It is obvious that neither the political society, nor the civil society were prepared to fully manage the new situation.

On the one side, the civic advocacy organizations succeeded to put into practice their blackmail potential in relation to the political elite. This result was facilitated by the convergence between the objectives of the external actors and those of the civil society. More, their success should be closely related to the continuous experience of public visibility and political contacting of the involved organizations, experience that maximized their capacity of bargaining.

However, these organizations have failed to a certain degree to reach the masses with their message, failure that might have consequences for the future basis of support of them. Especially in the case of the Coalition for a Clean Parliament, there was a non-negligible potential for the initiative to be interpreted as a political one by the citizens, with the connected consequences. In spite of all these reserves, the civic advocacy organizations' initiatives have put a supplementary pressure for accountability on the shoulders of the political elite, which might have turned transition politics into a new era.

On the other side, BNS's electoral involvement was another failure in the attempt to reassess the role of the trade unions in supporting collective rights. The electoral protocol with the Greater Romania Party (PRM) was an initiative with lose-lose outcome. It is also plausible to have consequences on the trade union bargaining and blackmail potential in relation to the government, since the cooperation with an anti-system, marginalized party as PRM was not at all a good label for BNS. 
A preliminary version of this article was presented at the American Political Science Association Annual Meeting in Washington DC, September 1-4, 2005, with the support of the APSA 2005 Travel Grant. In various stages of its development, the research for this article has been supported by the Open Society Institute Europe through the HESP Academic Fellowship Program (contract no. 80000159, Aurelian Muntean) and the Returning Scholarship Professional Development Fund and by the Romanian Higher Education Research Council (CNCSIS-UEFISCSU) through research grants A 382/2004 („Political Culture and Civic Engagement in Romania", grant director Gabriel Bădescu), PN II-IDEI 2174/2009 („,Romanian Presidential Election Study - 2009”, grant director Mircea Comşa) and the research scholarship BD 85/2003 (Andrei Gheorghiță).

\section{References:}

Almond, Gabriel, G. Bingham Powell, Jr., Kaare Strom and Russell J. Dalton. 2003. Comparative Politics Today. A World View. New York: Longman.

Bădescu, Gabriel. 2003. Social Trust and Democratization in PostCommunist Societies. In Social Capital and the Transition to Democracy, eds. Gabriel Bădescu and Eric M. Uslaner, 120-139. New York: Routledge.

Bjornlund, Eric C. 2004. Beyond Free and Fair. Monitoring Elections and Building Democracy. Washington: Woodrow Wilson Center Press.

Carothers, Thomas. 1996. Assesing Democracy Assistance: The Case of Romania. Washington: Carnegie Endowment for International Peace.

Chandler, David. 2004. Democratization in Bosnia: The Limits of Civil Society Building Strategies. In Civil Society in Democratization, eds. Peter Burnell and Peter Calvert, 225-249. London: Frank Cass.

Diamond, Larry. 1999. Developing Democracy. Toward Consolidation. Baltimore: The Johns Hopkins University Press.

Dryzek, John S. 1996. Political Inclusion and the Dynamics of Democratization. The American Political Science Review 90 (1): 475-487.

Elster, Jon, Claus Offe and Ulrich K. Preuss. 1998. Institutional Design in PostCommunist Societies. Cambridge: Cambridge University Press.

Howard, Mark Morje. 2003. The Weakness of Civil Society in Post-Communist Europe. Cambridge: Cambridge University Press.

Iankova, Elena. 2002. Eastern European Capitalism in the Making. Cambridge: Cambridge University Press.

Kubicek, Paul. 2004. Organized Labor in Postcommunist States. Pittsburgh: University of Pittsburgh Press.

Lipset, Seymour Martin, Martin A. Trow and James S. Coleman. 1956. Union Democracy. Glencoe: The Free Press.

Mungiu-Pippidi, Alina. 2005. Fighting Political Corruption in Postcommunist Europe. In A Quest for Political Integrity, 7-18. Iaşi: Polirom. 
Offe, Claus and Helmut Wiesenthal. 1985. Two Logics of Collective Action. In Disorganized Capitalism, ed. Claus Offe, pp. 175-220. London: Blackwell Polity Press.

Ost, David. 1993. The Politics of Interest in Post-Communist East Europe. Theory and Society 22 (4): 453-485.

Ost, David and Stephen Crowley. 2001. Making Sense of Labor Weakness in Postcommunism. In Workers after Workers' States. Labor and Politics in Postcommunist Eastern Europe, eds. Stephen Crowley and David Ost, 219-234. Lanham: Rowman and Littlefield.

Perez Diaz, Victor. 1993. The Return of Civil Society. Cambridge: Harvard University Press.

Tilly, Charles. 2004. Social Movements, 1768-2004. Boulder: Paradigm Publishers.

Tóka, Gábor. 2004. Partidele Politice în Europa Centrală şi de Est. In Cum se consolidează democrația, eds. Larry Diamond, Yun-han Chu, Marc F. Plattner, and Hung-mao Tien, 123-162. Bucureşti: Polirom.

Voicu, Bogdan. 2005. Penuria pseudo-modernă a postcomunismului românesc. Iaşi: Expert Projects.

***. 2005. Alegeri la limita democrației. Analiza procesului electoral din România, octombrie-decembrie 2004. Bucureşti: Pro Democracy Association Report.

***. 2005. Alegerile parlamentare şi prezidențiale 2004. Bucureşti: Institute for Public Policy Report.

***. 2005. Intărirea capacității instituționale a instituțiilor electorale: Autoritatea Electorală Permanentă şi Biroul Electoral Central. Bucureşti: CASP \& Romanian Society of Political Science Report. 